\title{
Effect of Precipitation Method on Properties of Hydroxyapatite Powders
}

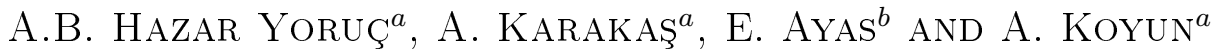 \\ ${ }^{a}$ Science and Technology Application and Research Center, Yildiz Technical University \\ 34349, Istanbul, Turkey \\ ${ }^{b}$ Materials Science and Engineering, Anadolu University, 26555, Eskişehir, Turkey
}

\begin{abstract}
The aim of this study was the compare the properties of hydroxyapatite as a function of two different methods (chemical and biomimetic precipitation). Powder products were called as chemical hydroxyapatite for chemical method and biomimetic hydroxyapatite for biomimetic method. Precipitated powders with both methods were characterized by Fourier transform infrared, X-ray diffraction, X-ray fluorescence and measurements of hardness and density. Chemical analysis results showed that dried-biomimetic hydroxyapatite sample consists of hydroxyapatite $\left.\left[\mathrm{Ca}_{10} \mathrm{PO}_{4}\right)_{6}(\mathrm{OH})_{2}\right]$ as main phase and beta-tricalcium phosphate $(\beta$-TCP) as secondary phase and dried-chemical hydroxyapatite sample also includes pure hydroxyapatite phase. Chemical hydroxyapatite and biomimetic hydroxyapatite powders were sintered using by spark plasma sintering method. Vickers hardness values of sintered disk samples were measured. Furthermore chemical structure of the final products was analyzed. Also density values of chemical hydroxyapatite and biomimetic hydroxyapatite disks were measured. Finally it is concluded that different precipitation methods affect hydroxyapatite properties and this can be an advantage for biomedical applications.
\end{abstract}

DOI: 10.12693/APhysPolA.123.371

PACS: $87.85 . \mathrm{J}-$

\section{Introduction}

Materials for all-ceramic restorations continue to receive growing interest in the dental research. Various novel ceramic materials and techniques have been introduced in the past decades [1]. Especially hydroxyapatite (HA) is a very attractive ceramic material for dental and biomedical applications since it is a main component of hard tissues such as bones and teeth. In order to improve critical mechanical properties of sintered HA, the properties of starting materials have been studied by controlling important parameters such as particle size and shape, particle distribution and agglomeration [2]. These properties of HA has been affected by synthesizing methods.

In literature, hydroxyapatite can be synthesized using many different methods such as sol-gel, microemulsion, hydrothermal, precipitation methods such as chemical and biomimetic. Among these methods, chemical and biomimetic precipitation are the common methods which provide pure product, useful and economic process [3]. Also it will be possible to obtain more biocompatible powders under the biological conditions. Another critical factor is the sintering behavior of $\mathrm{HA}$ and the densification properties which may be achieved by pressureless sintering, microwave sintering, hot-pressing and spark plasma sintering [2]. Fracture toughness $\left(K_{\mathrm{lc}}\right)$ of pure and dense HA ceramics is in the range of 0.8 1.2 $\mathrm{MPa}$. Bending strength, compressive strength and tensile strength of dense $\mathrm{HA}$ ceramics are 38-250 MPa, 120-900 MPa and 38-300 MPa, respectively. Young's modulus $(E)$ of dense HA ceramics is changed in the range of 35-320 GPa. Young's modulus measured in bending test is between $44 \mathrm{GPa}$ and $88 \mathrm{GPa}$. The Vickers hardness $(\mathrm{HV})$ of dense $\mathrm{HA}$ is between 3.0 GPa and
7.0 GPa. Moreover porosity is an important feature for hydroxyapatite based ceramics because porosity is decreasing bending strength, compressive strength and tensile strength in the ranges of 2-11 MPa, 2-100 MPa and $3 \mathrm{MPa}$, respectively $[4,5]$.

The purpose of this study is to investigate and compare the Vickers hardness of hydroxyapatite which has been synthesized by chemical and biomimetic methods.

\section{Materials and methods}

Hydroxyapatite was prepared by using chemical and biomimetic co-precipitation. In the chemical precipitation method, $\mathrm{Ca}\left(\mathrm{CH}_{3} \mathrm{COO}\right)_{2}$ and $\mathrm{NH}_{4} \mathrm{H}_{2} \mathrm{PO}_{4}$ materials were dissolved in deionized water separately. Then $\mathrm{NH}_{4} \mathrm{H}_{2} \mathrm{PO}_{4}$ solution was added dropwise in $\mathrm{Ca}\left(\mathrm{CH}_{3} \mathrm{COO}\right)_{2}$ solution and $\mathrm{pH}$ of the mixture was adjusted to 10 by using $\mathrm{NH}_{4} \mathrm{OH}$ solution $25 \%$. The mixture was vigorously stirred at room temperature for about $1 \mathrm{~h}$. After that, milky solution was aged for $24 \mathrm{~h}$ at room temperature and then dried at $80^{\circ} \mathrm{C}$ in air atmosphere. Dried samples were grinded by using mortar. This method and synthesized samples were called chemical precipitation method and chemical hydroxyapatite (CHA), respectively.

In the biomimetic precipitation method $\mathrm{Ca}\left(\mathrm{CH}_{3} \mathrm{COO}\right)_{2}$ and $\mathrm{NH}_{4} \mathrm{H}_{2} \mathrm{PO}_{4}$ were dissolved in simulated body fluids (SBF) separately. Then $\mathrm{NH}_{4} \mathrm{H}_{2} \mathrm{PO}_{4}$ solution was added dropwise in $\mathrm{Ca}\left(\mathrm{CH}_{3} \mathrm{COO}\right)_{2}$ solution and $\mathrm{pH}$ of the mixture was adjusted to 8 by using $\mathrm{SBF}: \mathrm{NH}_{4} \mathrm{OH}(2: 1)$ solution $25 \%$. The mixture was vigorously stirred at $37^{\circ} \mathrm{C}$ for about $1 \mathrm{~h}$. After that milky solution was aged for a $24 \mathrm{~h}$ at $37^{\circ} \mathrm{C}$, dried at $80^{\circ} \mathrm{C}$ in air atmosphere and dried samples were grinded. 
This method and synthesized samples were called as biomimetic precipitation method and biomimetic hydroxyapatite (BHA), respectively. SBF was prepared according to Tas's method [6].

BHA and CHA powders were sintered on spark plasma sintering (SPS-FCT GmbH FAST). HA powders were loaded in a graphite die and punch unit and graphite die were covered with graphite blanket to minimize the heat loss. Sintering was carried out at $900^{\circ} \mathrm{C}$ and $50 \mathrm{MPa}$ during 3 min.

Chemical structures of synthesized powders have been examined by the Fourier transform infrared (FTIR-Perkin-Elmer Spectrum-100) and X-ray diffraction (XRD-Philips, PW1710). Also the $\mathrm{Ca} / \mathrm{P}$ ratio of the samples was determined using X-ray fluorescence (XRF-Rigaku, ZSX Primus). Vicker's hardness test (EMCO-TEST M1C010) has been applied with the test load of $1000 \mathrm{~g}$ with a holding time 5. The Archimedes method was used to measure the density of sintered powders.

\section{Results and discussion}

FTIR analyses were carried out in the transmission mode in the mid-infrared range $\left(600-4000 \mathrm{~cm}^{-1}\right)$ at the resolution of $4 \mathrm{~cm}^{-1}$. Figure 1 shows the FTIR spectrum of $\mathrm{CHA}$ and BHA. The characteristic absorption peaks of samples CHA and BHA powders in the broad bands at 3432 and $1642 \mathrm{~cm}^{-1}$ were attributed to adsorbed water, while weak peak at $3571 \mathrm{~cm}^{-1}$ was attributed to the stretching vibration of the lattice $\mathrm{OH}^{-}$ions and the medium sharp peak at $633 \mathrm{~cm}^{-1}$ was assigned to the $\mathrm{O}-\mathrm{H}$ deformation. The characteristic bands for $\mathrm{PO}_{4}^{3-}$ appear at 964,1041 , and $1093 \mathrm{~cm}^{-1}$. Spark plasma sintered powders (CHA-S and BHA-S) are performed in the conditions of pressurized and heated environment which cause the release of water and decomposition from the materials. Moreover, decomposition of CHA-S powder has been more significant to compare with BHA-S. The characteristic $\mathrm{PO}_{4}^{3-}$ absorption bands of $\beta$-TCP were observed between the ranges of $900-1200 \mathrm{~cm}^{-1}$. Absence of $3571 \mathrm{~cm}^{-1}$ bands prove that the dehydroxylation of HA structure to the $\beta$-tricalcium phosphate $[\beta$-TCP; $\left.\mathrm{Ca}_{3}\left(\mathrm{PO}_{4}\right)_{2}\right]$. However BHA-S powder includes apatite $\left[\mathrm{Ca}_{10}\left(\mathrm{PO}_{4}\right)_{6} \mathrm{Cl}_{2}\right]$ as main phase in the structure $[7,8]$.

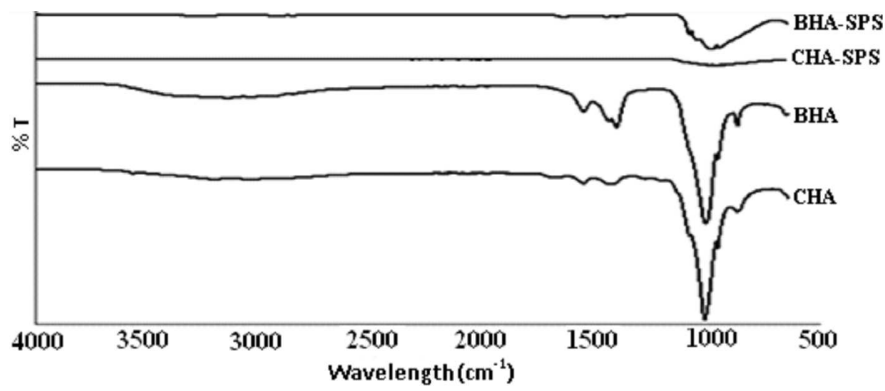

Fig. 1. FTIR spectrum of dried and sintered BHA and $\mathrm{CHA}$.
Figure 2 shows the XRD patterns of $\mathrm{CHA}$ and $\mathrm{BHA}$ powders. HA peaks occurred at $2 \theta$ of $28^{\circ}$ and $32^{\circ}$, which are consistent with the standard XRD peaks for HA. The XRD patterns of the dried CHA and BHA samples indicate that the main phase is HA and also there is $\beta$-TCP as secondary phase in the BHA structure. Even if in literature was said that HA could be synthesized with some impurities at initial $\mathrm{pH}$ values higher than 10 , our previous study [7] has proved that HA can be synthesized at low $\mathrm{pH}$ to compare with the literature [8]. Also XRD patterns of synthesized amorphous HA structure could be turned to crystalline phase when it was sintered at higher temperature. However the high sintering temperatures can be decomposed of HA structure as seen in Fig. 2. Sintered BHA and CHA samples are completely transformed to apatite $\left[\mathrm{Ca}_{5}\left(\mathrm{PO}_{4}\right)_{3} \mathrm{Cl}\right]$ and $\beta$-TCP $\left[\mathrm{Ca}_{3}\left(\mathrm{PO}_{4}\right)_{2}\right]$, respectively. This observation showed that different precursors [9] and precipitation methods could be affected by the final properties of synthesized HA at high temperature.

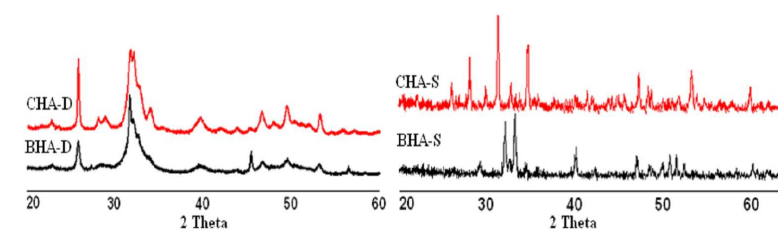

Fig. 2. XRD spectrum of dried and sintered BHA and CHA powders.

The Ca:P ratio and essential elements detected by $\mathrm{X}$-ray fluorescence (XRF) are outlined in Table I. Literature reports $\mathrm{Ca}: \mathrm{P}$ ratio in the range of $1.5-1.8$ in commercially available $\mathrm{HA}$ for different synthesizing methods [10]. According to XRF analysis Ca:P ratio was found higher than theoretical value of 1.67, indicating either the presence of excess $\mathrm{CaO}$ phase impurity, or phosphate deficiency in the powder specimens. CHA-S structure consisting of $\beta$-TCP is the main phase which is supported by FTIR and XRD results. $\mathrm{Mg}$ is the essential element in the structure. Moreover BHA-S sample contained $\mathrm{Na}, \mathrm{Mg}, \mathrm{K}$ and $\mathrm{Cl}$ as essential elements in addition to $\mathrm{SO}_{3}$ group. Presence of $\mathrm{Cl}$ element in the BHA-S structure supported the decomposition of apatite structure. Also existing of $\mathrm{SO}_{3}$ group proves phosphate deficiency in the BHA-S structure.

TABLE I

$\mathrm{XRF}$ results of sintered (at $\left.900{ }^{\circ} \mathrm{C}\right) \mathrm{CHA}$ and BHA powders.

\begin{tabular}{c|c|c|c|c|c|c|c|c}
\hline \hline [wt\%] & $\mathrm{CaO}$ & $\mathrm{P}_{2} \mathrm{O}_{5}$ & $\mathrm{Ca}: \mathrm{P}$ & $\mathrm{Na}_{2} \mathrm{O}$ & $\mathrm{MgO}$ & $\mathrm{K}_{2} \mathrm{O}$ & $\mathrm{SO}_{3}$ & $\mathrm{Cl}$ \\
\hline $\mathrm{CHA}$ & 52.5 & 38.9 & 1.71 & - & 0.2 & - & - & - \\
$\mathrm{BHA}$ & 53.4 & 35.3 & 1.92 & 6.2 & 0.8 & 0.3 & 0.2 & 3.0
\end{tabular}

The Vickers hardness and density values of the powders are given in Table II and images of hardness indentation were shown in Fig. 3. According to the images of the Vickers hardness indentation on the CHA-S disks, 
it can be said that CHA-S has homogeneous geometrical view to compare with BHA-S disk. For this reason CHA-S disk has higher hardness value than BHA-S sample. Literature has reported that hardness $(\mathrm{HV})$ value of dense HA is between $3.0 \mathrm{GPa}$ and $7.0 \mathrm{GPa}$ [11]. The hardness of ceramics depends on grain size and porosity, however some researchers reported that increase of the surface area changes hardness values of ceramic materials. For example, a 10-times increase in surface area produces $\approx 70 \%$ decrease in the Vickers hardness, $H_{\mathrm{V}}$. Also the hardness of HA is relatively insensitive to changes of secondary phases. This result explains that decomposition of the CHA and BHA during the SPS does not affect the hardness and density values of the powders. However higher surface area of the BHA powder cause a decrease in the Vickers hardness value.

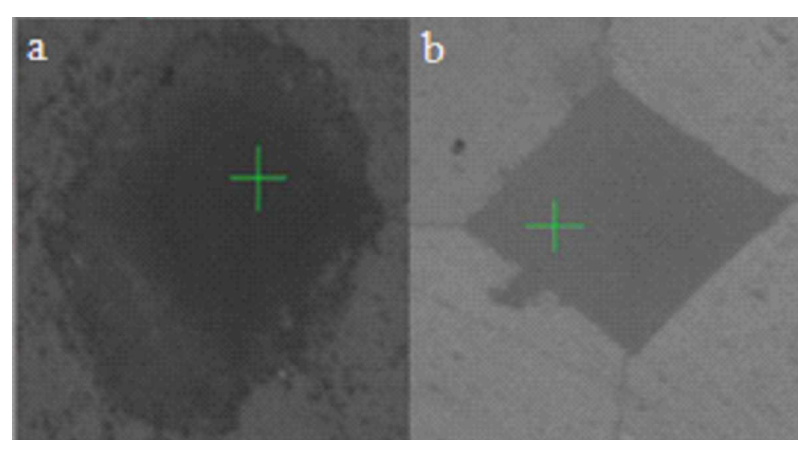

Fig. 3. Images of Vockers hafdness indentation on the (a) BHA-S and (b) CHA-S.

TABLE II

Vickers hardness and Archimedes density of CHA and BHA powders.

\begin{tabular}{c|c|c}
\hline \hline & $\begin{array}{c}\text { Vickers hardness } \\
H_{\mathrm{V}_{1}}[\mathrm{MPa}]\end{array}$ & $\begin{array}{c}\text { Archimedes } \\
\text { density }\end{array}$ \\
\hline CHA & $3.81 \pm 0.15$ & 2.86 \\
BHA & $2.90 \pm 0.08$ & 2.89
\end{tabular}

\section{Conclusion}

This study showed that XRD results of dried CHA and BHA powders include HA phase. However BHA powder consists of $\beta$-TCP as secondary phase. After the SPS process, composition of the BHA-D and CHA structures was transformed to $\beta$-TCP and apatite $\left[\mathrm{Ca}_{10}\left(\mathrm{PO}_{4}\right)_{6} \mathrm{Cl}_{2}\right]$, respectively. Moreover, sintered-BHA and $\mathrm{CHA}$ samples presented the same density values. BHA and CHA samples exhibited 3.81 and 2.90 MPa hardness values, respectively. SPS process changes the composition and hardness value of CHA and BHA samples but also does not change density values of the powders. Ca:P ratio of $\mathrm{BHA}$ has been higher than $\mathrm{CHA}, 1.97$ and 1.71 , respectively. If the $\mathrm{Ca} / \mathrm{P}$ molar ratio of $\mathrm{HA}$ is lower than $1.67, \beta$ or $\alpha$-tricalcium phosphate (TCP) forms in the structure. Decomposition process has a negative effect on the densification of the HA ceramics due to formation of a new phase and evaporation of water and consequently it decreases the strength of materials.

\section{Acknowledgments}

This study was supported, in part, by the Turkish Scientific and Technical Research Foundation (TUBITAK) within the scope of the project number 110M182 and by the Yildiz Technical University, Science and Technology Application and Research Center.

\section{References}

[1] I.L. Denry, J.A. Holloway, Dental Mater. 20, 213 (2004).

[2] G. Muralithran, S. Ramesh, Ceram. Int. 26, 221 $(2000)$

[3] N. Monmaturapoj, C. Yatongchai, Bull. Mater. Sci. 34, 1733 (2011).

[4] R.I. Martin, P.W. Brown, J. Mater. Sci. Mater. Med. 6, 138 (1995)

[5] W. Suchanek, M. Yoshimura, J. Mater. Res. 13, 94 (1998).

[6] A.C. Tas, Biomaterials 21, 1429 (2000).

[7] A. Rapacz-Kmita, C. Paluszkiewicz, A. Slosarczyk, Z. Paszkiewicz, J. Mol. Struct. 744-747, 653 (2005)

[8] M.S.M. Arsad, P.M. Lee, L.K. Hung, in: 2nd Int. Conf. on Biotechnology and Food Science-2011, Singapore 2011, p. 184.

[9] A. Karakas, A.B. Hazar Yoruc, D. Ceylan Erdoğan, M. Doğan, Acta Phys. Pol. A 121, 236 (2012).

[10] F.C.M. Driessens, M.G. Boltong, E.A.P. de Maeyer, R. Wenz, B. Nies, J.A. Planell, $01016 /$ S01429612(02)00151-5Biomaterials 23, 4011 (2002).

[11] K.L. Aw, R. Tolouei, S. Ramesh, C.Y. Tan, W.H. Yeo, H. Kelvin, I. Sopyan, W.D. Teng, Adv. Mater. Res. 264-265, 1538 (2011) 